\title{
MOTIVASI DAN PERSEPSI WISATAWAN NUSANTARA KE JATILUWIH, TABANAN
}

\author{
Ni Made Ayu Diah Utari ${ }^{1}$, NMS. Wijaya ${ }^{2}$, I Putu Sudana ${ }^{3}$ \\ Email:kddiahutari@gmail.com¹, mdsofiawij@gmail.com², sudanaputu@gmail.com ${ }^{3}$ \\ ${ }^{1,2,3}$ Program Studi Industri Perjalanan Wisata, Fakultas Pariwisata, Universitas Udayana
}

\begin{abstract}
This research is done by four national tourist motivations namely physical motivation, culture motivation, social motivation, and fantasy motivation. Perception of domestic tourists is assessed from the tourism component, namely attraction, accesibility, amenities, ancilary services. This research has a purpose 1) to determine the motivation of Indonesian tourists visiting Jatiluwih tourist attraction, Tabanan regency. 2) to find out the perception of Indonesian tourists about the main components in tourism (4A) in the tourist attraction of Jatiluwih, Tabanan regency. This research uses purposive sampling method with the method of taking informants is accidental sampling and distributing questionnaires to 125 respondents of domestic tourists. The data collection tehniques used were observatio, interview, questionnaires, literature study, documentary study and the data analysis tehniques were descriptive qualitative and quantitative descriptive. The results of this study indicate that the highest motivation for domestic tourists to visit Jatiluwih tourist attraction is to enjoy the natural atmosphere and terraced rice fields, Jatiluwih ia a World Cultural Heritage, to interact with local people or farmers in Jatiluwih, and to seek new experiences. The perception of tourists towards the main components in tourism in the overall research is good. However, tourists feel that they are lacking in ancilary service on the indicator of the availability of ATM because these facilities are inadequate.
\end{abstract}

Abstrak: Dalam penelitian ini digunakan empat motivasi wisatawan nusantara yaitu motivasi fisik, motivasi budaya, motivasi sosial, dan fantasy motifasi. Persepsi wisatawan nusantara dinilai dari komponen pariwisata yaitu atraksi, akses, fasilitas, layanan tambahan. Penelitian ini dilakukan pada daya tarik wisata jatiluwih kabupaten tabanan. Penelitian ini bertujuan 1) Untuk mengetahui motivasi wisatawan Nusantara yang berkunjung ke daya tarik wisata Jatiluwih, Kabupaten Tabanan. 2) Untuk mengetahui persepsi wisatawan Nusantara terhadap komponen utama dalam pariwisata (4A) pada daya tarik wisata Jatiluwih, Kabupaten Tabanan. Penelitian ini menggunakan metode penentuan sampel bersifat purposive dengan metode pengambilan informan bersifat accidental sampling dan melakukan penyebaran kuesioner kepada 125 responden wisatawan nusantara. Teknik pengumpulan data yang digunakan adalah observasi, wawancara, kuesioner, studi kepustakaan, studi dokumetasi dan dengan teknik analisis data secara deskriptif kualitatif dan deskriptif kuantitatif. Hasil dari penelitian ini menunjukan bahwa motivasi tertinggi wisatawan nusantara untuk berkunjung ke daya tarik wisata jatiluwih untuk menikmati suasana alam dan sawah terasering, jatiluwih merupakan warisan budaya dunia, untuk berinteraksi dengan masyarakat setempat atau petani di Jatiluwih, dan untuk mencari pengalaman baru. Persepsi wisatawan terhadap komponen utama dalam pariwisata pada penelitian secara keseluruhan sudah baik. Namun wisatawan merasa kurang pada ancilary service pada indikator tersedianya ATM karena fasilitas ini belum memadai.

Keywords: motivation, perception, jatiluwih. 


\section{PENDHULUAN}

Pariwisata merupakan salah satu aspek penting dari suatu negara didunia internasional. Semakin meningkatnya perkembangan sektor pariwisata menunjukkan bukti keberhasilan pembangunan yang dapat dilakukan oleh pemerintah Indonesia. Bali adalah salah satu daerah tujuan wisata di Indonesia yang mampu menarik minat wisatawan. Pulau Bali yang terkenal di mancanegara maupun nusantara, sehingga banyak dikunjungi oleh wisatawan, baik wisatawan asing maupun wisatawan nusantara karena daya tarik wisata pulau Bali yang memukau wistawan baik dari kebudayaannya yang unik, adat istiadat yang berlandaskan pada konsep keserasian dan keselarasan yang dapat mewujudkan kondisi estetika yang ideal dan bermutu tinggi. Selain adat dan budayanya Bali dikenal memiliki potensi alam yang sangat indah, diantaranya iklim yang tropis,danau, gunung, hutan yang hijau, sawah, sungai dan pantai indah dengan beragam pasir hitam dan putih. Meskipun Bali sebuah pulau kecil yang luasnya hanya $0,29 \%$ dari luas Nusantara $(5.632,86 \mathrm{~km} 2)$, tapi memiliki semua unsur lengkap dan wisatwan yang datang untuk menghabiskan liburan di Bali tidak pernah merasa bosan dan jenuh, karena dapat menemukan suasana baru serta atraksi yang menarik dan unik untuk dinikmati.

Berdasarkan data dari BPS, dapat diketahui bahwa jumlah kunjungan wisatawan domestik yang datang ke Bali. Pada tahun 2014 jumlah kunjungan wisatawan domestik sebesar 6.394.307 kunjungan, kemudian pada tahun 2015 jumlah kunjungan wisatawan domestik meningkat sejumlah 7.147.100 dengan persentase pertumbuhan sebesar $11.77 \%$, tahun berikutnya 2016 persentase pertumbuhan meningkat menjadi 20.94\% dengan jumlah kunjungan wisatawan domestik yang meningkat secara signifikan sebesar 8.643.680, kemudian pada tahun 2017 jumlah kunjungan wistawan domestik sebesar 8.735.633 kunjungan dengan persentase pertubuhan sebesar $1.06 \%$, kemudian pada tahun 2018 mengalami peningkatan jumlah kunjungan wisatawan domestik sebesar 9.757.991 dengan peningkatan persentase pertumbuhan sebesar $11.70 \%$. Disimpulkan bahwa jumlah kunjungan wisatawan domestik setiap tahunnya mengalami peningkatan yang signifikan, peningkatan yang terjadi dipengaruhi oleh minat wisatawan untuk mengunjungi Bali sebagai tempat untuk melakukan liburan atau rekreasi.

Kabupaten Tabanan merupakan salah satu wilayah di Bali yang terkenal akan pariwisatanya. Terletak dibagian selatan pulau Bali, kabupaten Tabanan memiliki luas wilayah $839,33 \mathrm{~km}^{2}$ (14,90 dari luas pulau Bali) yang terdiri dari pegunungan dan pantai. Suasana agraris yang ada dan keasriannya menjadikan budaya masyarakat begitu menarik bagi wisatawan. Kehidupan beragama, seni budaya dengan beragam budaya tari-tarian yang unik beserta budaya pertanian dengan sistem subak. Pariwisata di Kabupaten Tabanan sudah terkenal di mata wisatawan, pada tahun 2018 Kementrian Pariwisata yang diwakii oleh tenaga ahli menteri pariwisata bidang pemasaran dan kerjasama, I Gede Pitana memberikan sebuah apresiasi untuk pemerintah kabupaten Tabanan yang telah ditetapkan sebagai kabupaten dengan destinasi pariwisata terbaik di Indonesia. Apresiasi diberikan pada perhelatan festival Jatiluwih.

Salah satu daya tarik yang terkenal di Tabanan adalah Jatiluwih, Jatiluwih terletak di Kecamatan Penebel, adapun letak geografis wilayah pada daya tarik Jatiluwih yaitu dengan luas total kurang lebih $33,22 \mathrm{~km}^{2}$,yang memiliki ketinggian kurang lebih 1.059 di atas permukaan laut dengan suhu udara rata-rata 19 derajat Celsius. Jatiluwih sangat terkenal dengan daerah pertanian dimana mayoritas petani sebagai mata pencaharian dari masyarakat setempat, Jatiluwih terkenal akan sawah yang terasering atau berundag-undag. Selain akan keindahan pemandangan sawah, Jatiluwih juga memiliki keindahan akan pemandangan gunung Batukau. Jatiluwih merupakan kawasan terbesar pemandangan sawah di Bali dengan luas 636 hektar. Selain itu jatiluwih juga menyuguhkan keindahan air terjun, suasana pedesaan dengan rumah tradisional khas Bali. Dengan mengandalkan wisata berbasis pertanian, yang paling terkenal di jatiluwih adalah sistem pertanian subak yang merupakan sistem organisasi pertanian yang menggunakan konsep Tri Hita Karana yaitu hubungan manusia dengan manusia, manusia dengan alam, dn manusia dengan Tuhan. Jatiluwih juga dinobatkan sebagai 
warisan budaya dunia yang ditetapkan oleh UNESCO pada 29 Juni 2012. Semenjak itu pariwisata di Jatiluwih semakin ramai dikunjungi oleh wisatawan dari mancanegara maupun wisatawan nusantara. Dari data yang di dapat tripadvisor Jatiluwih mendapat peringkat satu pada objek wisata terpopuler di kabupaten Tabanan. Selain akan keindahan alam Jatiluwih juga terkenal dengan budayanya, salah satunya yaitu Jatiluwih telah menggelar beberapa festival yang diselenggarakan dari tahun 2017.

$$
\text { Menurut sumber media }
$$

suaradewata.com (selasa, 26/09/2017) (menurut ketua 1 badan pengelola DTW di Jailuwih Nengah Kartika). Peningkatan kunjungan wisatawan april 2017 sebanyak 19.277, bulan mei 2017 sebanyak 20.377, juni 2017 sebanyak 21.569, juli 2017 sebanyak 29.324 dan agustus 2017 sebanyak 41.654 kunjungan wisatawan. Jika dilihat tahun 2016 pada bulan april 2016 sebanyak 13.869 kunjungan, mei 2016 sebanyak 17.066, juni 2016 sebanyak 15.432, bulan juli sebanyak 23.590 dan bulan agustus 2016 sebanyak 35.918 kunjungan wisatawan. Menurut Sutirtayasa dari pengelola DTW Jatiluwih tahun 2018 dari awal tahun sampai April 2018 yaitu total kunjungan sebanyak 57.606 dan akan bertambah di bulan berikutnya seiring dengan libur. Pada tahun 2019 dari bulan Januari hingga bulan oktober total kunjungan mencapai 271.777. Pada tahun 2020 kunjungan wisatawan mengalami penurunan karenakan Pemerintah Kabupaten Tabanan melakukan penutupan sementara sejumlah objek wisata dari 22-30 Maret 2020, slah satu DTW yang ditutup yaitu DTW Jatiluwih. Penutupan yang dilakukan karena penyebaran virus corona atau Covid-19.

Melihat dari jumlah kunjungan wisatawan yang dijelaskan di atas bahwa sebelum terjadi penyebaran virus Covid-19 kunjungan wisatawan dilihat semakin meningkat dan mengalami penurunan ketika objek wisata ditutup sementara. Maka dari itu peneliti ingin mengangkat DTW Jatiluwih sebagai topik penelitian. Permasalahan yang diangkat yaitu motivasi berkunjung dan persepsi wisatawan pada DTW Jatiluwih, Tabanan. Penelitian ini penting dilakukan, karena mengingat dengan mengetahui motivasi dan persepsi wisatawan pada DTW Jatiluwih maka dapat diketahui alasan wisatawan berkunjung. Sedangkan permasalahan tentang persepsi penting dilakukan agar pihak pengelola mengetahui persepsi dari wisatawan mengenai DTW Jatiluwih, yang nantinya dapat memberikan kontribusi pada perbaikan dan peningkatan pengelolaan.

\section{METODE}

Studi penelitian ini dilakukan di daya tarik wisata Jatiluwih, Kabupaten Tabanan. Jatiluwih dapat ditempuh $40 \mathrm{~km}$ dari kota Denpasar. Batas-batas wilayah desa Jatiluwih meliputi, sebelah utara: Hutan Negara, Sebelah timur: Desa Senganan, sebelah barat: Desa Wongaya Gede, sebelah selatan: Desa Babahan,. Lokasi penelitian ini dipilih karena Jatiluwih merupakan destinasi dengan daya tarik keindahan sawah terasering dan salah satu yang terkenal di Tabanan. sehingga dapat dimungkinkan untuk dikaji tentang motivasi dan persepsi wisatawan nusantara yang melakukan kunjungan di DTW Jatiluwih dan dapat memperoleh jawaban yang digunakan sebagai masukan untuk pengelolaan DTW Jatiluwih dalam jangka panjang.

Variabel yang digunakan yang digunakan peneliti adalah Motivasi yang terdiri dari Physical Motivation, Culture Motivation, Sosial Motivation Dan Fantasy Motivation, dimana motivasi ini merupakan faktor internal yang datang dari diri wisatawan itu sendiri. Peneliti akan mencari tahu bagaimana motivasi wisatawan nusantara dengan indikator dari masing-masing variabel tersebut. Kemudian persepsi yang digunakan peneliti terdiri dari attraction, amenities, accesibility, ancilary service, yang tergolong ke dalam komponen utama dalam pariwisata (4A), dimana persepsi ini merupakan faktor eksternal yang ada pada wisatawan. Peneliti akan mencari tahu bagaimana persepsi wisatawan nusantara dari indikator pada masing-masing variabel persepsi.

Teknik pengumpulan data dilakukan dengan metode observasi, wawancara, kuesioner, studi kepustakaan, studi dokumentasi. Pada teknik penentuan sampel, penentuan sampel ditunjukan kepada wisatawan nusantara yang pernah berkunjung ke DTW Jatiluwih yang bersedia memberikan informasi/ jawaban mereka atas pertanyaan yang diberikan oleh peneliti atau yang sedang 
berkunjung pda DTW Jatiluwih.. Teknik penentuan sampelnya disebut purposive. Jumlah sampel pada penelitian yang akan di ambil menggunakan saran dari Hair et al (2016:166), menyatakan bahwa untuk mengukur ukuran sampel dihitung antara 5 atau 10 dikalikan jumlah indikator pada penelitian. Meihat dari rumus Hair at al maka perkalian yang digunakan pada penelitian ini adalah 5 , dengan jumlah indikator yaitu 25 Maka jumlah sampel yang akan digunakan adalah 5 × $25=125$ sampel, jumlah tersebut diharapkan mampu mewakili populasi.

Teknik Pengambilan Informan, pengambilan informan dilakukan dengan teknik Accidental Samping, berdasarkan kebetulan dan dirasa mampu sebagai sumber data yang memenuhi syarat dalam mengisi kuesioner dan mampu memberikan jawaban yang tepat untuk pertimbangan pengetahuan dan pengalaman yang dimiiki (Sugiyono, 2006). Teknik Angket atau Kuesioner dalam penelitian ini, peneliti menggunakan teknik purposive sampling dengan mencari responden yang telah berkunjung atau sedang berkunjung ke daya tarik wisata Jatiluwih. Dalam teknik angket atau kuesioner peneliti menggunakan google form sebagai alat untuk menyebarkan kuesioner data penelitian.

Teknik Analisis Data dalam penelitian ini menggunakan analisi data secara deskriptif kuaitatif dan deskriptif kuantitatif. Analisis deskriptif kualitatif yaitu gambaran yang disusun secara istematis, aktul dan akurat tentang fakta-fakta yang ada. Data kualitati cendrung berbentuk kata-kata (Arikunto, dalam penelitian Witarsanan, 2017), data pada penelitian yang termasuk data kualitati yaitu dalam deskripsi tentang lokasi penelitian yang diperkuat dengan gambar-gambar dan keterangan yang mendukung kesimpulan penelitian..Sedangkan deskriptif kuantitatif adalah data berupa angka-angka yang dapat diklarifikasikan.

Untuk mengukur motivasi berkunjung dan persepsi wisatawan, maka peneliti menggunakan Skala Likert. Skala Likert adalah suatu skala psikometrik yang umum digunakan dalam kuesioner, dan merupakan skala yang banyak digunakan dalam riset berupa survey.. Penilaian Skala Likert terdiri dari sangat setuju, setuju, ragu-ragu, tidak setuju, dan sangat tidak setuju . Namun peneliti hanya menggunakan empat penilaian antara lain: Skor empat diberikan apabila responden memberikan tanggapan/ penilaian yang sangat baik, skor tiga diberikan apabila responden memberikan tanggapan/ penilaian yang baik, skor dua diberikan apabila responden memberikan tanggapan/ penilaian yang buruk, skor satu diberikan apabila responden memberikan tanggapan/ penilaian yang sangat buruk.

\section{HASIL DAN PEMBAHASAN \\ Gambaran Umum Lokasi Penelitian}

Daya tarik wisata Jatiluwih terletak di kecamatan Penebel, kabupaten Tabanan, berada pada ketinggian 700 meter di atas permukaan air laut yang terkenal dengan keindahan sawah terasering. Luas sawah sekitar 636 hektar dengan sistem menggunakan sistem pengairan sawah subak. Wisata Jatiluwih terletak $48 \mathrm{~km}$ dari kota Denpasar. Lokasinya $28 \mathrm{~km}$ di bagian utara kota Tabanan. Jatiluwih juga terkenal dengan potensi budayanya salah satunya adalah upacara keagamaan yang dirayakan setiap 210 hari sekali. Pada upacara puncaknya dipentaskan tarian wali pendet sakral, tarian ini jarang dipentaskan, kecuali pada hari perayaan sebuah upacara.

Jatiluwih awal mulanya berasal dari kata "jaton dan luwih". Jaton yang artinya jimat, sedangkan luwih artinya bagus, dari arti kata tersebut dapat disimpulkan Jatiluwih mempunyai arti sebuah desa yang memiliki jimat yang benar-benar bagus atau ampuh. Pada sumber lain diceritakan bahwa di tengah desa Jatiluwih ada sebuah kuburan binatang purba yaitu seekor burung Jatayu. Dari kata Jatayu kemudian mengalami perubahan bunyi menjadi Jaton Ayu yang berarti luwih atau bagus jadi dapat disimpulkan Jaton Ayu sama dengan Jatiluwih. Dari arti Jailuwih tersebut dibuktikan dengan adanya hasil dari bertani dan berkebun yang bisa memenuhi kebutuhan masyarakat di Desa Jatiluwih.

Karena keindahan hamparan sawah terasering, Jatiluwih akhirnya ditetapkan oleh UNESCO sebagai warisan budaya dunia, Sejak Jatiluwih mulai diakui oleh dunia, masyarakat setempat mulai menyadari akan adanya potensi yang dimiliki dari desa Jatiluwih sebagai desa wisata. Kemudian akhirnya Desa Jatiluwih diciptakan dan 
menawarkan konsep pariwisata berbasis pertanian yang meliputi studi wisata yang mendidik pengunjung tentang, subak, sawah dan berbagai kegiatan petani di Jatiluwih

Fasilitas-fasilitas yang ada pada daya tarik wisata jatiuwih yang bisa diberikan kepada wisatawan yaitu: Loket Tiket, Information post, Homestay atau Villa, Wisata Bersepeda, Restaurant dan Warung makan, Camping Ground, Guava Agro, Yeh Ho Waterfall, Trakking Path.

\section{Karakteristik Wisatawan Nusantara}

Dilihat dari asal daerah bahwa wisatawan yang berasal dari Bali berjumlah 61 orang dengan jumlah presentase sebesar $48.8 \%$ terlihat pada tabel bahwa yang berasal dari Bali memiliki nilai persentase yang cukup tinggi dikarenakan wisatawan yang berasal dari Bali tergolong wisatawan yang melakukan liburan staycation, wisatawan yang tergolong staycation ini yaitu wisatawan yang melakukan liburan masih dalam wilayahnya dengan liburan yang dilakukan di rumah dan melibatkan perjalanan ke atraksi-atraksi lokal yang berada di sekitar area tempat tinggal. Kemudian tertinggi kedua terlihat pada tabel selanjutnya wisatawan yang berasal dari jawa timur berjumlah 16 orang dengan jumlah presentase sebesar $12.8 \%$, berasal dari jawa barat berjumlah 9 orang dengan persentase $7.2 \%$, berasal dari Jawa Tengah dengan persentase sebesar $8 \%$ berjumlah 10 orang, berasal dari banten berjumlah sebanyak 5 orang dengan persentase sebesar $4 \%$, berasal dari jakarta dengan persentase sebesar 9.6\% berjumlah 12 orang, berasal dari Kalimantan Utara dengan persentase sebesar $2.4 \%$ berjumlah 3 orang , berasal dari Sumatra Utara berjumlah 5 orang dengan jumlah persentase $4 \%$, serta berasal dari Sumatra Selatan berjumlah 3 orang dengan jumlah persentase sebesar $2.4 \%$, dan yang paling terendah yaitu wisatawan yang berasal dari timor leste dengan persentase sebesar $0.8 \%$ berjumlah 1 orang.

Karakteristik wisatawan berdasarkan umur yaitu wisatawan yang berumur kurang dari 20 tahun $(<20$ tahun) sebanyak 6 orang dengan presentase $4.8 \%$. Kedua wisatawan yang berumur 21-30 tahun dengan persentase $94.4 \%$ sebanyak 118 orang. Hal ini juga disebabkan karena didiominasi oleh orang yang termasuk kedalam golongan milenial, dimana golongan milenial lahir pada 19801990, atau pada awal 2000 dan seterusnya yang aktif pada media sosial. Ketiga berumur 31-40 tahun sebanyak 1 orang dengan persentase $0.8 \%$, umur ini cendrung pada mereka yang sudah berumah tangga dan sibuk pada aktifitas di keluarga, jadi terlihat pada penelitian sangat sedikit terlihat. wisatawan yang berumur lebih dari 40 tahun ( $>40$ tahun) dinyatakan bahwa tidak ada.

Karakteristik wisatawan berdasarkan pendidikan terakhir wisatawan yaitu berpendidikan sekolah dasar tidak ada, berpendidikan sekolah menengah atas/ sekolah menengah kejuruan (SMA/SMK) sebanyak 56 orang dengan persentase $44.8 \%$, kemudian berpendidikan sarjana dengan presentase $37.6 \%$ sebanyak 47 orang, berpendidikan Diploma dengan persentase $16.85 \%$ sebanyak 21 orang, dan berpendidikan sekolah menengah pertama sebanyak 1 orang dengan persentase $0.8 \%$. Dijelaskan bahwa yang paling tertinggi terlihat pada yang berpendidikan SMA/SMK.

Karakteristik wisatawan nusantara berdasarkan pekerjaan yaitu yang paling banyak wisatawan yang bekerja sebagai pegawai swasta sebanyak 62 orang dengan presentase sebesar $49.6 \%$, mahasiswa dengan presentase sebesar $34.4 \%$. hal ini disebabkan karena mayoritas pegawai swasta merupakan wisatawan yang memiliki lebih banyak budget untuk berwisata kemudian untuk wisatawan nusantara yang bekerja sebagai mahasiswa itu disebabkan karena mereka lebih banyak memiliki waktu untuk melakukan aktifitas untuk berwisata padas uatu daya tarik khususnya daya tarik wisata Jatiluwih. Kemudian pengusaha dengan persentase $8.8 \%$, keempat pegawai negeri (PNS) dengan persentase $2.4 \%$, kelima bekerja sebagai analis kesehatan dengan presentase $1.6 \%$ dan sebagai pelajar/ siswa dengan persentase $1.6 \%$, kemudian terakhir paling rendah yaitu sebagai dokter dan IRT sebanyak 1 orang dengan persentase sebesar $0.8 \%$.

Karakteristik wisatawan nusantara berdasarkan frekwensi kunjungan yaitu kunjungan pertama kali sebanyak 43 orang dengan persentase $34.4 \%$, wisatawan nusantara yang melakukan kunjungan 2 kali orang dengan persentase $30.4 \%$ sebanyak 38 , 
wisatawan nusantara yang melakukan kunjungan 3 - 4 kali dengan persentase $35.2 \%$ sebanyak 44 orang dapat dijelaskan bahwa dari semua frekwensi kunjungan memiliki selisih persentase yang yang hampir mendekati, dijelskan bahwa kunjungan yang dilakukan wisatawan lebih banyak dari dua kali sampai terbanyak empat kali, karena dilihat pada rentan umur 21-30 itu merupakan rentan umur yang paling banyak memiliki waktu senggang dalam aktifitasnya, jadi dominan lebih banyak bisa melakukan kegiatan berwisata.

Karakteristik wisatawan nusantara yang berdasarkan sumber informasi yaitu wisatawan nusantara yang mendapat informasi dari teman yaitu sebanyak 53 orang dengan persentase $42.4 \%$, wisatawan nusantara yang mendapat informasi dari media sosial yaitu dengan persentase $44 \%$ sebanyak 55 orang, wisatawan nusantara yang mendapat informasi dari keluarga yaitu dengan persentase $9.6 \%$ sebanyak 12 orang, wisatawan nusantara yang mendapat informasi dari media cetak yaitu dengan persentase 4\% sebanyak 5 orang. Dapat dijelaskan bahwa wisatawan nusantara yang paling banyak mendapatkan informasi yaitu melalui media sosial. Disebabkan karena yang pling banyak berkunjung yaitu pada rentan umur 21-30 dimana pada umur ini wisatawan cendrung termasuk kedalam generasi yang masih aktif atau dapat dibilang generasi milenial yang dimana paling aktif di media sosial

Karakteristik wisatawan nusantara yang dilihat berdasarkan tempat penginapan yaitu wisatawan menginap di rumah keluarga/ teman dengan presentase $47.2 \%$ sebanyak 59 orang, wisatawan nusantara yang menginap di Hotel dengan presentase $31.2 \%$ sebanyak 39 orang, wisatawan nusantara yang menginap di villa dengan presentase $15.2 \%$ sebanyak 19 orang, yang terakhir yaitu wisatawan yang menginapdi hostel dengan presentase sebesar $6.4 \%$ sebanyak 8 orang. Dapat disimpulkan bahwa wisatawan nusantara paling banyak menginap di rumah keluarga atau teman yaitu mahasiswa yang dikatakan memiliki lebih sedikit budget untuk melakukan wisata jadi mereka lebih memilih menginap di rumah teman atau keluarga.

\section{Motivasi Berkunjung Wisatawan Nusantara pada Daya Tarik Wisata Jatiluwih \\ Variavbel Physical motivation pada} indikator mengunjungi DTW jatiuwih untuk melakukan relaksasi atau membuat pikiran menjadi tenang dan santai dengan rata-rata 3,54 dengan kategori sangat setuju. Pernyataan mengunjungi DTW Jatiluwih untuk menikmati suasana alam dan terasering sawah dengan rata-rata 3,58 yang dengan kategori sangat setuju. Variabel Culture motivation pada indikator mengunjungi DTW jatiluwih untuk belajar dan mengenal budaya subak dengan rata-rata 3,03 dengan kategori setuju., mengunjungi DTW Jatiluwih untuk melihat dan mengetahui kegiatan petani dengan ratarata 2,95 dengan kategori setuju, mengunjungi DTW Jatiluwih karena warisan budaya dunia dengan rata-rata 3,39 dengan kategori sangat setuju. Variabel social motivation pada indikator berkunjung ke DTW jatiluwih untuk mengunjungi teman atau keluarga dengan rata-rata 2,38 dengan kategori tidak setuju, mengunjungi DTW jatiluwih untuk dapat berinteraksi dengan masyarakat setempat atau petani di jatiluwih dengan rata-rata 2,84 dengan kategori setuju. Variabel fantasy motivation pada indikator berkunjung ke daya tarik Jatiluwih untuk bersantai dan menikmati kuliner di restaurant atau café di sekitar wisata Jatiluwih dengan rata-rata 3,18 dalam kategori setuju, berkunjung ke daya tarik wisata Jatiluwih untuk mendapatkan pengalaman baru dengan rata-rata 3,39 yang dalam kategori sangat setuju.

Berdasarkan dari seluruh pernyataanyang dilihat dari 125 responden wisatawan nusantara skor tertinggi yaitu skor 4 berdasarkan tabel skala likert yaitu 1) mengunjungi DTW jatiuwih untuk melakukan relaksasi atau membuat pikiran menjadi tenang dan santai, 2) mengunjungi DTW jatiluwih untuk menikmati suasana alam dan terasering sawah, 3) mengunjungi DTW jatiluwih karena merupakan warisan budaya dunia, 4) berkunjung ke DTW jatiluwih untuk mendapatkan pengalaman baru. Dari keempat pernyataan di atas menyatakan bahwa termasuk kedalam kategori sangat setuju.

Hal tersebut menunjukan bahwa physical motivation, culture motivation, sosial motivaion, dan fantasy motivation mendorong 
wisatawan nusantara untuk berkunjung ke daya tarik wisata Jatiluwih. Hal ini terlihat karena dengan karakteristik wisatawan yang kebanyakan masih mahasiswa dan paling banyak yaitu pegawai swasta yang dalam kesehariannya bergelut pada mata pelajaran dan pekerjaan yang menjenuhkan. Motivasi wisatawan dari 125 jumlah responden yang berkunjung pada DTW jatiluwih, total keseluruhan memperoleh skor 2828 dengan rata-rata 3,14 yang dapat digolongkan kedalam kategori setuju.

\section{Persepsi Wisatawan Nusantara yang Berkunjung pada Daya tarik Wisata Jatiluwih}

Persepsi terhadap variabel atraksi pada indikator Keindahan sawah terasering pada daya tarik wisata jatiluwih dengan rata-rata 3,62 dengan kategori sangat baik. indikator Jalur treking yang nyaman pada area sawah di daya tarik wisata Jatiluwih dengan rata-rata 3,40 dengan kategori sangat baik. Indikator kegiatan bersepeda pada jalur treking yang bisa dilakukan wisatawan pada DTW Jatiluwih dengan rata-rata 3,30 dalam kategori sangat baik. Indikator adanya sistem irigasi tradisional Bali (subak) yang masih tetap terjaga kelestariannya dengan rata-rata 3,59 dalam kategori sangat baik. indikator Adanya aktivitas sehari-hari petani di sawah pada daya tarik Jatiluwih dengan rata-rata 3,22 yang termsuk kedalam kategori baik.

Variabel amenities pada indikator tersedianya publik toilet yang memadai dan bersih pada DTW Jatiluwih dengan rata-rata 3,04 dalam kategori baik. Indikator ketersediaan lahan parkir luas pada DTW Jatiluwih yang mendapatkan rata-rata 2,98 yang dengan kategori baik. Indikator tersedianya tempat sampah yang memadai dan bersih pada DTW jatiluwih dengan jumlah rata-rata 3,14 dengan kategori baik. Indikator tersedianya restaurant dan rumah makan yang bersih dan nyaman pada DTW Jatiluwih dengan jumlah rata-rata sebesar 3,30 dalam kategori sangat baik. indikator tersedianya penginapan atau Homestay pada DTW Jatiluwih dengan jumlah rata-rata sebesar 3,20 dengan kategori baik.

Variabel accesibility pada indikator ketersediaan jalan utama atau alternatif menuju daya tarik wisata Jatiluwih dengan jumlah rata-rata 3,22 dengan kategori baik. indikator tersedianya akses jalan penghubung yang baik dengan menghubungkan wisata jatiluwih dengan tempat wisata lainnya dengan rata-rata 3,10 yang termasuk kedalam kategori baik. Indikator tersedianya akses treking yang bagus untuk dapat menikmati keindahan sawah terasering di jatiluwih dengan rata-rata 3,30 yang termasuk kedalam kategori sangat baik

Variabel ancilary service pada indikator adanya pusat informasi yang tepat dan baik bagi wisatawan di DTW jatiluwih dengan ratarata 3,14 termasuk kedalam kategori baik. Indikator ketersediaan loket pembayaran tiket masuk yang baik pada daya tarik wisata Jatiluwih dengan jumlah rata-rata 3,07 yang termasuk kedalam kategori baik. Indikator tersedianya ATM yang memadai pada DTW Jatiluwih dengan rata-rata 2,79 yang termasuk kedalam kategori baik.

Berdasarkan 125 jumlah responden wisatawan nusantara, dari keseluruhan variabel. Variabel atraksi yang mendapatkan perolehan tertinggi yaitu pada indiktor adanya sistem irigasi tradisional Bali (subak) yang masih tetap terjaga kelestariannya yaitu dengan perolehan skor 359 dengan rata-rata 3,59 yang tergolong dalam kategori sangat baik. Indikator tersebut sekaligus menjadi indikator yang tertinggi dari semua indikator yang ada. Sehingga pernyataan tersebut menyatakan bahwa persepsi wisatawan terhadap adanya sistem irigasi tradisional Bali (subak) yang masih tetap terjaga bisa dikatakan sangat baik. Hal tersebut diperkuat dengan hasil wawancara dari wisatawan nusantara yang berkunjung pada daya tarik wisata jatiluwih.

"saya berkunjung ke daya tarik wisata adalah untuk mencari suasana baru, mencari pengalaman baru terhadap budaya, khususnya budaya subak yang memang sudah terkenal dan ingin berinteraksi dengan masyarakat lokal atau petani setempat agar bisa lebih tau mengenai budaya yang ada di jatiuwih". (Arka Putra, Jawa Barat, hasil wawancara 2 november 2020)".

Dapat disimpulkan bahwa dari 125 jumlah responden keseluruhan jumlah skor pada variabel persepsi wisatawan nusantara 
pada daya tarik wisata Jatiluwih yaitu sebesar 5141 dengan rata-rata 3,19 yang tergolong kedalam kategori baik.

\section{SIMPULAN DAN SARAN Simpulan}

Berdasarkan latar belakang dan pembahasan dalam penelitian ini maka dapat disimpulkan sebagi berikut:

1. Motivasi wisatawan

Pada pyscal motivasi mendapatkan perolehan skor tertinggi pada indikator menikmati suasana alam dan terasering sawah dengan rata-rata 3,58. kemudian pada culture motivasi mendapatkan skor tertinggi dengan kategori sangat setuju dengan rata-rata 3,39 karena Jatiluwih merupakan warisan budaya dunia. Pada social motivasi mendapatkan skor tertinggi pada pernyataan karena untuk dapat berinteraksi dengan masyarakat setempat atau petani di Jatiluwih dengan rata-rata 2,84. Terakhir pada fantasy motivasi dengan perolehan skor tertinggi mendapatkan satu pernyataan dengan kategori sangat setuju dengan rata-rata 3,39 karena untuk mendapatkan pengalaman baru . Dapat disimpulkan bahwa motivasi dari 125 jumlah responden wisatawan yang berkunjung pada daya tarik wisata jatiluwih, total keseluruhan memperoleh skor 2828 dengan rata-rata 3,14 yang dapat digolongkan kedalam kategori setuju.

2. Persepsi Wisatawan terhadap komponen utama pariwisata (4A) pada daya tarik wisata Jatiluwih

Pada komponen atractionmendapat skor tertinggi pada rata-rata 3,59 karena adanya sistem irigasi tradisional bali (subak) yang masih terjaga kelestariannya. Pada komponen amenities terdapat satu pernyataan dengan skor tertinggi pada kategori sangat baik dengan rata-rata 3,30 karena tersedianya restoran dan rumah makan yang bersih dan nyaman. Kemudian pada komponen accesibility mendapatkan skor tertinggi dengan rata-rata 3,30 karena tersedianya akses treking yang bagus untuk menikmati keindahan sawah terasering. Terakhir pada komponen ancilary serviceyang mendapatkan skor tertinggi pada kategori baik dengan rata-rata 3,14 karena adanya pusat informasi yang tepat dan baik. Dengan demikian dari 125 jumlah responden keseluruhan jumlah skor pada variabel persepsi wisatawan nusantara pada daya tarik wisata jatiluwih yaitu sebesar 5141 dengan rata-rata 3,19 yang tergolong kedalam kategori baik.

\section{Saran}

1. Saran kepada pihak pengelola daya tarik wisata yaitu fasilitas penunjang agar perlu ditingkatkan lagi, seperti melakukan perluasan lahan parkir agar ketika terjadi kepadatan pengunjung pada daya tarik lahan parkir dapat menampung banyak kendaraan kemudian bisa terlihat lebih rapi.

2. Saran kepada pihak pengelola daya tarik wisata jatiluwih untuk dapat lebih mengoptimalkan fasilitas seperti ATM agar wisatawan dapat lebih mudah dalam melakukan transaksi pada daya tarik wisata jatiluwih

3. Saran kepada pihak pengelola daya tarik wisata jatiluwih agar tetap menjaga kelestarian daya tarik wisata seperti: membatasi dalam pembangunan pada kawasan hijau atau lahan pertanian pada daya tarik wisata Jatiluwih 


\section{Kepustakaan}

Anonim Undang-undang tentang Kepariwisataan, UU No. 10 Tahun 2009. Jakarta: Direktorat Jenderal Hukum dan HM.

Arikunto,S. 2002. Metodologi Penelitian Suatu Pendekatan Proposal. Jakarta: PT. Rineka Cipta.

Fandeli, Chafid. 1995. Dasar-dasar Manajemen Kepariwisataan Alam. Yogyakarta: Liberti.

Ismayanti. 2010. Pengantar Pariwisata. Jakarta: PT Gramedia Widisarana Indonesia.

Jonathan, Sarwono. 2006. Metode Penelitian Kuantitatif dan Kualitatif. Yogyakarta: Graha Ilmu.

Kotler. 1993. Manajemen Pemasaran (Analisis Perencanaan, Implementasi, dan pengendalian). Jakarta: Lembaga Penerbit Fakultas Ekonomi Universitas Indonesia.

Mardalis. 2008. Metodelogi Penelitian:Suatu Pendekatan Proposal. Jakarta: Bumi Aksara.

Mclntosh, W.,Goeldner, C.R.Ritchie, J.R.B., 1995,Tourism: Principles, Practices, Philosophies, John Wiley \& Sons, Inc.,New York.

Pitana, I Gede dan Gayatri, Putu G. 2005. Sosiologi Pariwisata. Yogyakarta: Penerbit Andi.

Sanjaya, Wina.2013. Penelitian Pendidikan, Jenis, Metode dan Prosedur. Jakarta: Kencana Prenada Media Group.

Sharpley, R (1994). Tourism, Tourism and Socciety. Cambridgeshire: ELM Publication.

Soekadijo,R.G, 2000, Anatomi Pariwisata, Jakarta: Gramedia Pustaka Utama.

Sugiyono. (2006) Metode Penelitian Pendidikan Kuantitatif Kualitatif dan R\&D. Bandung: Alfabeta.

Sujarweni, Wiratna. 2014. Metodelogi Penelitian: Lengkap, praktis dan Mudah dipahami. Yogyakart: PT Pustaka Baru.

Sutrisno Hadi, (1986) Metodologi Research Jilid 1, Yogyakarta: Fakultas Psikologi UGM.

Suwena, I Ketut, Widyatmaja, I Gst Ngr, 2017, Pengetahuan Dasar Ilmu Pariwisata, Denpasar, Pustaka Larasan.
Suwena, Widyatmaja, 2010. Pengetahuan Dasar Ilmu Pariwisata. Denpasar: Udayana University Press.

Wahab, Salah 1975. Tourism Managemet. London. Tourism International Press.

Winardi, J. 2000. Motivasi dan Pemotivasian dalam Manajemen. Jakarta: Raja Grafindo Persada.

Yoeti. Oka. 1995. Pengantar Ilmu Kepariwisataan (edisi 1). Yogyakarta: Erlangga. 